\title{
The Idea of Your Lips
}

\author{
Nicole Brossard
}

\section{L'idée de vos lèvres}

Écrit en anglais, ce texte explore l'émergence d'un sujet femme quand une femme assume pleinement ses désirs pour une autre femme. Le désir d'une fermme appelle le désir d'une autre femme. L'érotique est le site d'une emotion/motivation, qui produit du plaisir et de la reconnaissance activant une nouvelle aire d'interprétation, le lieu d'un politique lesbien qui bascule l'ordre symbolique.

I remember one evening in a bar of a small American city, we were four women - three lesbians, one heterosexual - and we were talking about literature, writing and desire. ${ }^{1}$ Then suddenly one of the women asked around: 'What turns you on?' Spontaneously I answered: 'Words.' And we all agreed until one woman insisted, 'words especially in the mouth of an intellectual woman'. Then we argued about the word intellectual for some three hours of passionate discussion. During those three hours, though it seemed we were talking about intellectuals, knowledge, social classes and racism, I can say we did enter a highly erotic atmosphere.

On a very hot afternoon in Florence, while eating and drinking good wine with three Italian lesbians, they started telling me how for fun they had imagined a club where lesbians could be matched together on the basis of their sexual fantasies and preferences: big or flat bellies, shape of the hands, of lips, younger or olderwoman, butch or femme, etc.

One day, in Barcelona, a woman asked to buy two copies of Under tongue, one for her, one for a woman she said she had in mind for the evening. The next day, I asked her how was her evening and she answered: 'The book - it worked.' ${ }^{1}$ 


\section{The Idea of Your Lips · 127}

One day, my lesbian friend Rosanna who works at the Women's Book Shop in Rome, told me how she had answered two American lesbians who were asking for books with lesbian S/M images or stories. She told them that having grown up in a Roman Catholic environment full of martyrs (bondage, crucifixion, etc.) Italian lesbians were not particularly interested in that material.

From these four stories I am tempted to conclude that:

1) being among lesbians is already erotic;

2) eroticism can be triggered by details as well as by major movements of the soul;

3) words are always a good erotic start whether they are written or spoken;

4) though lesbians through time and space share some erotic approaches and sexual practices, there are some socio-cultural environments which make us value differently what is erotic or aesthetic;

5) eroticism is at the heart of lesbians' life.

And it is on this the fifth statement that I would like to talk for a moment.

Why is it that the sexual/erotic attraction we have toward women takes so much space in our daily life and thoughts? Is it because we don't know how to draw the line between eroticism, friendship or a work relationship? For me there is no reason to draw a line between those three realities of our lives because lesbian erotic attraction keeps shifting from memory to identity, from sexual arousal to emotional overwhelm, from fantasies to values, from details to essential soul's movement and vice-versa? In other words, lesbian desire has no rest. It is a subtle, floating desire which binds lesbians to lesbians but also lesbians to other women, it is a key element inspiring projects and activating creativity. In fact, I would say that lesbian desire is a nomadic desire, for example a desire able to focus intensely though momentarily on many women in the same evening.

Sometimes our desire can be totally absorbed in one woman, but still we keep travelling in our lesbianship toward a new world which each woman represents. For we are definitely interested in women, by women at all levels because we have great expectations about them 
and especially about lesbians. What kind of expectations? Expectations that can keep up with the positive, strong, autonomous, creative image that we project on them. This positive image that we project on lesbians is an image we long for in ourselves or that we feel is deeply rooted in ourselves. In fact, this image is part of us whether as dream or as certitude. Having expectations in that sense about women means that we give to the other woman symbolic significance; in other words, she is attributed a power to echo in us a meaning essential to what we are. Because of that our desire goes in her direction. She arouses our desire which is curious, fascinated, eager to approach her in her most intimate reality. We want something of her: her thoughts, her story, her ideas. We want her attention. We want more. We want to get closer, as close maybe as to share her jouissance. Her attention, her pleasure are really and symbolically meaning to us.

This kind of attention we have for other women and the kind of attention they have for us is absolutely subversive in the symbolic order. Because of that, when we reach for the other woman, whether with our eyes, our hands or with words, we reach at the same time for an act of love which bears in itself what I would call an unidentified political statement. Though, I suppose, we never think consciously about that when we feel an erotic attraction for other women, I would say that this political statement which starts in the choice we make of another woman for sexual bliss finds its way in our pleasure in a very subtle manner. It opens up along with pleasure our imagination and our thoughts so they can blossom in our mind in such a beautiful way that there is no more space for old thoughts or, if some are still left, pleasure and recognition activate them in a totally new realm of interpretation. The 'unidentified' political statement reinforces the bond with the other woman. That is why to me lesbian politics are unthinkable outside lesbian eroticism. This also probably explains why the erotic emotion/motivation we bear in ourselves is at the heart of our lesbian life like a precious material which helps us to find a direct route to our values and priorities.

Now that this has been said, let's get closer to see the way she moves, she speaks, indeed the way she has of arousing something in you which yet you don't identify but which is moving its way in your gut, in your mind, which is indeed putting you in such an emotional acuity 
that you are getting ideas. Desire calls for desire. Desire calls for images, tasty images, salty metaphors. So let's get closer to find out if your skin likes her skin, if you like her smell, if you like the way she moves her tongue when kissing, now let's look at her eyes from as close as can be, from this distance where I have always thought that all women are beautiful because their eyes can in no way escape what they mean.

Now let us get definitively intimate. Now let the bodies move along their story and see to what kind of rhythm they will attune, what kind of story they will narrate in their movements, in the way she touches and likes being touched, in the way she looks at you and likes being looked at. Let's see if her whole family is in the bed, if her childhood is in the bed, if her ex-lovher ${ }^{2}$ is in the bed. Let's see if we are really alone with only the music of the sounds we make. Let's see if we have been making love together in another life, if from eternity we have known each other. Let's see if we can postpone eternity. Let's see if you still have the energy to keep you eyes open when you say this absolute yes.

Je cherche la réalité dans tes yeux et d'autres soupirs encore, rondeurs encore de nos voix emmêlées.

Let's see if I will end my paper by saying that lesbian eroticism is a way to move along with our priorities which are women as the subject of interest, of identity, as the subject of great expectations, and as the subject of our own desire. Let's see if we can trace back in her eyes and each of her cells, who we were, who we are, who we are to be.

\section{Notes}

1. This text was written in English and delivered as a talk for a panel on 'Clit Lit' at the Words Without Borders Literary Festival of Gay Games III, Celebration 90, held in Vancouver, August 1990.

2. In reference to Barbara Godard's translation of Amantes, which was published by Guernica Press, Montréal, 1986 under the title Lovhers. 